\title{
Relaxin Is a Key Mediator of Prostate Growth and Male Reproductive Tract Development
}

\author{
Chrishan S. Samuel, Hongsheng Tian, Ling Zhao, and Edward P. Amento
}

Molecular Medicine Research Institute (CSS, HT, EPA), Sunnyvale, Departments of Medicine (EPA) and Dermatology (CSS, EPA), Stanford University School of Medicine, Stanford, California; and Howard Florey Institute of Experimental Physiology and Medicine (LZ), University of Melbourne, Victoria, Australia

\begin{abstract}
SUMMARY: Male mice deficient in relaxin showed retarded growth and marked deficiencies in the reproductive tract within 1 month of age. At 3 months of age, male reproductive organ weight (including the testis, epididymis, prostate, and seminal vesicle) from relaxin null $(R L X-/-)$ mice were significantly $(p<0.05)$ smaller than those of wild-type $(R L X+/+)$ male mice. Histologic examination of $\mathrm{RLX}-/-$ mouse tissues demonstrated decreased sperm maturation (testis), increased collagen, and decreased epithelial proliferation in the prostate compared with tissues obtained from $\mathrm{RLX}+/+$ animals. The degree of sperm maturation in the testes of sexually mature RLX $-/-$ mice ( 3 months) resembled that of immature ( 1 month) $R L X+/+$ mice and correlated with a decrease in fertility in RLX $-/-$ mice. The marked differences in the extracellular matrix of the testis and prostate in RLX-/males also correlated with an increase in the rate of cell apoptosis. Relaxin and LGR7 (relaxin receptor) mRNA expression was demonstrated in the prostate gland and testis of the normal mouse. Data from this study demonstrate that relaxin is an important factor in the development and function of the male reproductive tract in mice and has an essential role in the growth of the prostate and maintenance of male fertility. Relaxin may mediate its effects on growth and development by serving as an antiapoptotic factor. (Lab Invest 2003, 83:1055-1067).
\end{abstract}

$R$ elaxin is a dimeric peptide hormone that belongs to the insulin family of peptides (Schwabe and McDonald, 1977), with a number of functions commonly associated with the female reproductive tract (Sherwood, 1994). These actions include the ability to inhibit myometrial contractions and soften the uterine cervix, vagina, and interpubic ligament by remodeling collagen in preparation for mammalian parturition. Furthermore, reports of additional actions of relaxin in tissues (Tan et al, 1999) and cells (Parsell et al, 1996; Unemori and Amento, 1990; Wyatt et al, 2002) outside the female reproductive tract and the localization of relaxin binding sites in the heart and brain (Osheroff et al, 1992; Osheroff and Ho, 1993; Osheroff and Phillips, 1991) have expanded the role of relaxin from a hormone of pregnancy to a growth factor/cytokine. Immunoreactive relaxin and relaxin-binding sites have also been detected within the male reproductive tract: in the prostate (Ivell et al, 1989; Yki-Jarvinen et al, 1983), the seminal fluid (Essig et al, 1982; Weiss et al, 1986; Winslow et al, 1992), testis (Min and Sherwood, 1998), and spermatozoa (Carrell et al, 1995). In contrast to mammals where relaxin is produced in the prostate (Ivell et al, 1989; Yki-Jarvinen et al, 1983), the

\section{DOI: 10.1097/01.LAB.0000079784.81186.B9}

Received April 15, 2003.

Address reprint requests to: Dr. Edward P. Amento, Molecular Medicine Research Institute, 525 Del Ray Avenue, Sunnyvale, CA 94085. E-mail: eamento@mmrx.org; Dr. Chrishan S. Samuel, Howard Florey Institute of Experimental Physiology and Medicine, University of Melbourne, Victoria 3010,Australia.E-mail: c.samuel@hfi.unimelb.edu.au testis appears to be the major source of relaxin in some species (Steinetz et al, 1998). From these initial findings, it was suggested that relaxin may be involved in increasing sperm motility (Weiss, 1989) and enhancing the ability of sperm to penetrate the cervical mucus (Brenner et al, 1984).

To identify the physiologic function of relaxin, the relaxin gene knockout mouse was established (Zhao et al, 1999, 2000), which has led to the confirmation of several relaxin-dependent phenotypes, established earlier in ovariectomized pregnant rats (Hwang et al, 1991; Kuenzi and Sherwood, 1992). Pregnant relaxindeficient mice showed impaired mammary gland and nipple development, as did relaxin-deficient (ovariectomized) pregnant rats. Unlike $\mathrm{RLX}+/+$ mice, the nipples of pregnant $R L X-/-$ mothers did not grow, and the nipple histology retained the appearance of the virgin state; hence, pups could not suckle unless cross-fostered to an RLX wild-type or heterozygous foster mother.

Although many studies have investigated a role for relaxin during pregnancy (Goldsmith et al, 1995; Sherwood, 1994; Zhao et al, 1999, 2000) and as a potential therapeutic agent against fibrotic diseases (Unemori et al, 1993, 1996), to date the role of relaxin during normal mammalian growth and development is yet to be determined. Importantly, a potential role for relaxin in the growth and regulation of the male reproductive tract has not been addressed in detail; however, there is limited evidence showing that relaxin may contribute to testicular descent during late pregnancy in rats (Parry et al, 2001). Hence, the aim of this study is to investigate 
the potential role of relaxin in this developmental process by examining reproductive tissues during maturation of the male reproductive tract in relaxindeficient mice.

Mice lacking a functionally active relaxin gene showed growth retardation and marked deficiencies in male reproductive tract development, particularly evident in a lack of growth of the prostate. Changes also included decreased sperm maturation, an increase in markers for apoptosis and changes in the extracellular matrix architecture and glandular elements of the prostate.

\section{Results}

\section{Growth and Maturation of Mice}

There were no significant differences in body weights of male and female relaxin wild-type $(+/+)$, heterozygous $(+/-)$, and null mutant $(-/-)$ mice at 1 week of age (Fig. 1). At 1 month of age, however, mean body weights of both $\mathrm{RLX}-/-$ males (17.05 \pm $0.65 \mathrm{~g})$ and females (14.77 $\pm 0.42 \mathrm{~g})$ were significantly less $(p<0.05)$ than aged-matched $R L X+/+$ mice (males: $18.92 \pm 0.61 \mathrm{~g}$; females: $16.34 \pm$ $0.51 \mathrm{~g})$. Male and female $\mathrm{RLX}-/-$ mice were also significantly $(p<0.05)$ smaller than $R L X+/+$ animals at 2 months of age, but the differences in size between the two groups were less than that observed at 1 month of age. By adulthood ( 3 months of age), the difference in body weight between $\mathrm{RLX}+/+$ and $\mathrm{RLX}-/-$ mice was no longer significant. No significant differences were observed be- tween the average weight of $\mathrm{RLX}+/+$ and $\mathrm{RLX}+/-$ animals or between $R L X+/-$ and $R L X-/-$ mice. Additionally, there were no significant differences in hematology, plasma chemistry, or urine analysis of male $R L X+/+$ and $R L X-/-$ mice.

\section{The Male Reproductive Tract}

From 1 week to 1 month of age, there appeared to be no significant changes in the overall weight of the male reproductive tract between groups (Table 1 ). By adulthood (3 months of age), there was a significant $(p<0.05)$ difference in the overall weight of the male reproductive tract (Table 1 ) as well as the size of individual organs. The weight of the reproductive tract in normal mice increased $148.6 \%$ from 1 month to adulthood and represented $3.37 \%$ of the total body weight. In contrast, the weight of the reproductive tract of male $\mathrm{RLX}$-null mutant mice only increased by $87.9 \%$ and represented $2.33 \%$ of the total body. The change in the weight ratio of reproductive tract to body weight between $\mathrm{R} L \mathrm{X}+/+$ and $R L X-/-$ mice represented a difference of $31 \%$. The size of the individual tissues (testis, prostate, epididymis, and seminal vesicle) from $R L X-/-$ mice also appeared to be smaller than the same tissues derived from $\mathrm{RLX}+/+$ mice.

\section{Histology of the Male Reproductive Tract}

Sections of male reproductive tissue from $\mathrm{RLX}+/+$ and $\mathrm{RLX}-/$ - mice were examined for sperm content, tubule size and compactness (testis and epididymis),

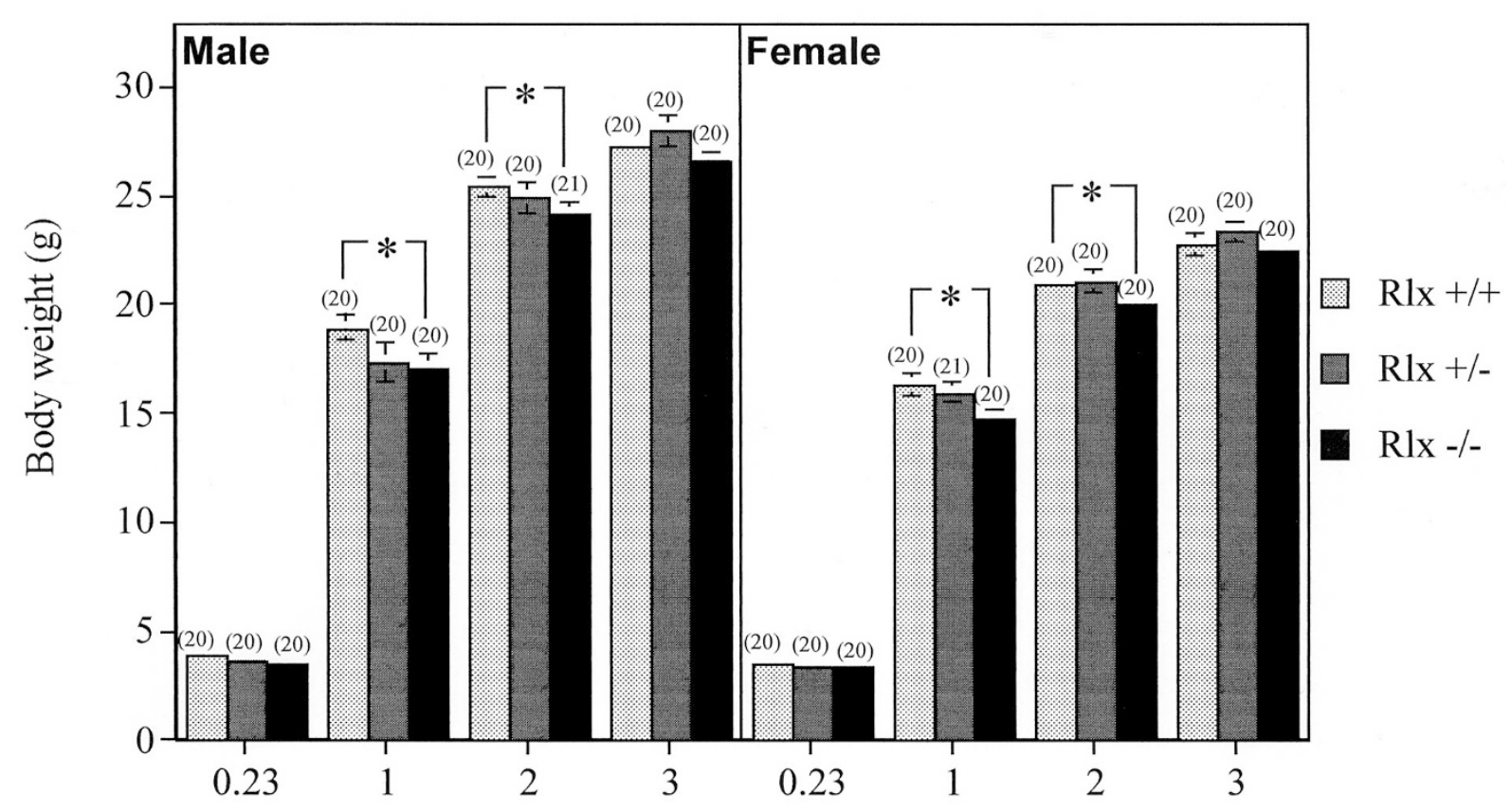

Age of mice (months)

Figure 1.

The mean ( $\pm \mathrm{SE}$ ) body weights of male and female relaxin $\mathrm{RLX}+/+(\square), \mathrm{Q} L X+/-(\square)$, and $\mathrm{RLX}-/-(\square)$ mice from birth to adulthood (3 months of age). The number of animals used in each group are presented above each bar. An asterisk denotes a difference of $p<0.05$ between $\mathrm{RLX}+/+$ and $\mathrm{RLX}-/-\mathrm{groups}$ only. 
Table 1. The Weight of the Male Reproductive Tract from 1 Week of Age to Adulthood (3 Months)

\begin{tabular}{lcccc}
\hline & $\begin{array}{c}\text { RLX }+/+ \\
{[\text { Mean } \pm \text { SE }(\mathrm{n})]}\end{array}$ & $\begin{array}{c}\text { \% of body } \\
\text { weight }\end{array}$ & $\begin{array}{c}\text { RLX-/- } \\
{[\text { Mean } \pm \text { SE }(\mathrm{n})]}\end{array}$ & $\begin{array}{c}\% \text { of body } \\
\text { weight }\end{array}$ \\
\hline 1 week of age & $0.017 \pm 0.001 \mathrm{~g}(10)$ & 0.43 & $0.018 \pm 0.002 \mathrm{~g}(15)$ & 0.53 \\
1 month of age & $0.37 \pm 0.02 \mathrm{~g}(11)$ & 1.81 & $0.33 \pm 0.01 \mathrm{~g}(11)$ & 1.77 \\
3 months of age & $0.92 \pm 0.06 \mathrm{~g}(14)$ & 3.37 & $0.62 \pm 0.03 \mathrm{~g}(11)^{a}$ & 2.33 \\
\hline
\end{tabular}

${ }^{a}$ Difference of $p<0.05$.

glandular development (prostate), and interstial collagen. Several differences were evident.

At 1 month of age, seminiferous tubules of the testis of $\mathrm{RLX}-/-$ mice appeared to contain less immature sperm than that found in RLX+/+ mice (Fig. 2, A to D). By adulthood (3 months), testis tubules of RLX+/+ mice contained an abundance of mature sperm, which was clearly observed in the center of each tubule (Fig. $2, E$ and $G$ ), in contrast to tubules of $R L X-/-$ mice that contained immature sperm (Fig. 2, $\mathrm{F}$ and $\mathrm{H}$ ).

By as early as 1 week of age, testis tubules of RLX - / - mice were associated with increased collagen staining (Fig. 3B), compared with levels detected in $\mathrm{RLX}+/+$ mice (Fig. 3A). This trend in increased collagen (between tubules) was also observed in adult RLX-/- mice (Fig. 3D) and was associated with more densely packed tubules, compared with that found in tissues from wild-type mice (Fig. 3C).

No difference in the epididymis was noted until 3 months of age, when tubule compactness and increased collagen staining were more evident in tissues derived from RLX-/- mice (Fig. 3F). Mature sperm content of epididymis tubules of $\mathrm{RLX}-/-$ mice was decreased compared with that observed in $R L X+/+$ mice, consistent with observations in the testis.

The most significant morphologic differences associated with a lack of relaxin were noted in the prostate. We found that the prostate from RLX-null mice did not undergo an age-related increase in growth. This was associated with a decrease in glandular epithelial growth and increased interstitial collagen (Fig. 3, H and $\mathrm{J}$ ), compared with that found in $\mathrm{RLX}+/+$ mice (Fig. 3, G and I). The decreased epithelium (in RLX-/mice) was characterized by an increase in cuboidal (low secretory) cells and decreased tall columnar (increased secretory) cells (Fig. 4).

\section{Measurement of Collagen within the Male Reproductive Tract}

The hydroxyproline (collagen) content from 6-monthold $\mathrm{RLX}+/+$ and $\mathrm{RLX}-/-$ mice was determined in male reproductive tissues (prostate, testis, and epididymis) to confirm and quantitate the increased collagen, observed by histology. The collagen content of animals was conducted on slightly older animals to confirm the hypothesis that relaxin-deficient mice undergo a progressive increase in collagen with age, resulting in elevated collagen deposition (as observed in other tissues [Amento et al, 2001; Samuel et al, 2003]) by approximately 6 months of age. As demonstrated in Figure 5, the greatest increase in collagen expression was seen in the prostate of $\mathrm{RLX}-/$ - mice, which had $40 \%(p<0.05)$ more collagen than that measured in $\mathrm{RLX}+/+$ mouse prostate tissues. The testis of RLX $-/-$ mice also had significantly higher ( $p$ $<0.05$ ) levels of collagen expression (19\%), compared with levels measured in the testes of $R L X+/+$ mice. Although the epididymis of RLX $-/-$ mice had a $12 \%$ increase in collagen expression compared with levels measured in $\mathrm{RLX}+/+$ mice, this increase in epididymal collagen was not statistically significant (Fig. 5).

\section{Detection of Cell Apoptosis}

Based on observations showing decreased sperm content (testis) and epithelial cell activity (prostate) in $\mathrm{RLX}-/$ - mice, we investigated an association of these findings with alterations in apoptosis or cell replication.

\section{Bax and Caspase-9 Antibody Staining}

Overexpression of Bax accelerates apoptotic death induced by cytokine deprivation and also counters the death repressor activity of Bcl-2 (Oltvai et al, 1993). Caspase-9, a central death protease, belongs to a unique family of cysteine proteases that differ in sequence, structure, and substrate specificity to other described protease families (Kuida, 2000). The caspase family members (which are usually involved in a cascade of proteolytic cleavage events) function as key components of the apoptotic machinery by destroying specific target proteins that are critical to cellular activity. Using monoclonal antibodies to Bax and caspase-9, we examined the in vivo distribution of the Bax and caspase- 9 proteins in the male reproductive tissues.

Bax staining was primarily observed in the germinal cells near the basement membrane (Fig. 6, A to F) but was not associated with mature sperm cells. Seminiferous tubules derived from immature (1 month) RLX $-/-$ mice contained significantly $(p<0.05)$ higher levels of Bax-positive cells (dark-brown cell staining; Figure 6B) compared with tissues from $\mathrm{RLX}+/+$ mice (Fig. 6A; Table 2). Adult (3 month) RLX $+/+$ mouse testes had decreased Bax staining (Fig. 6D) compared with immature mice. In contrast, the slower rate of tissue maturity observed in RLX-/- mouse testes correlated with a significant increase in Bax staining with age (Fig. 6E; Table 2). Similar findings were observed in epididymis tubules from immature and adult RLX $-/-$ mice (Fig. 6, G to L). Epithelial cells of 


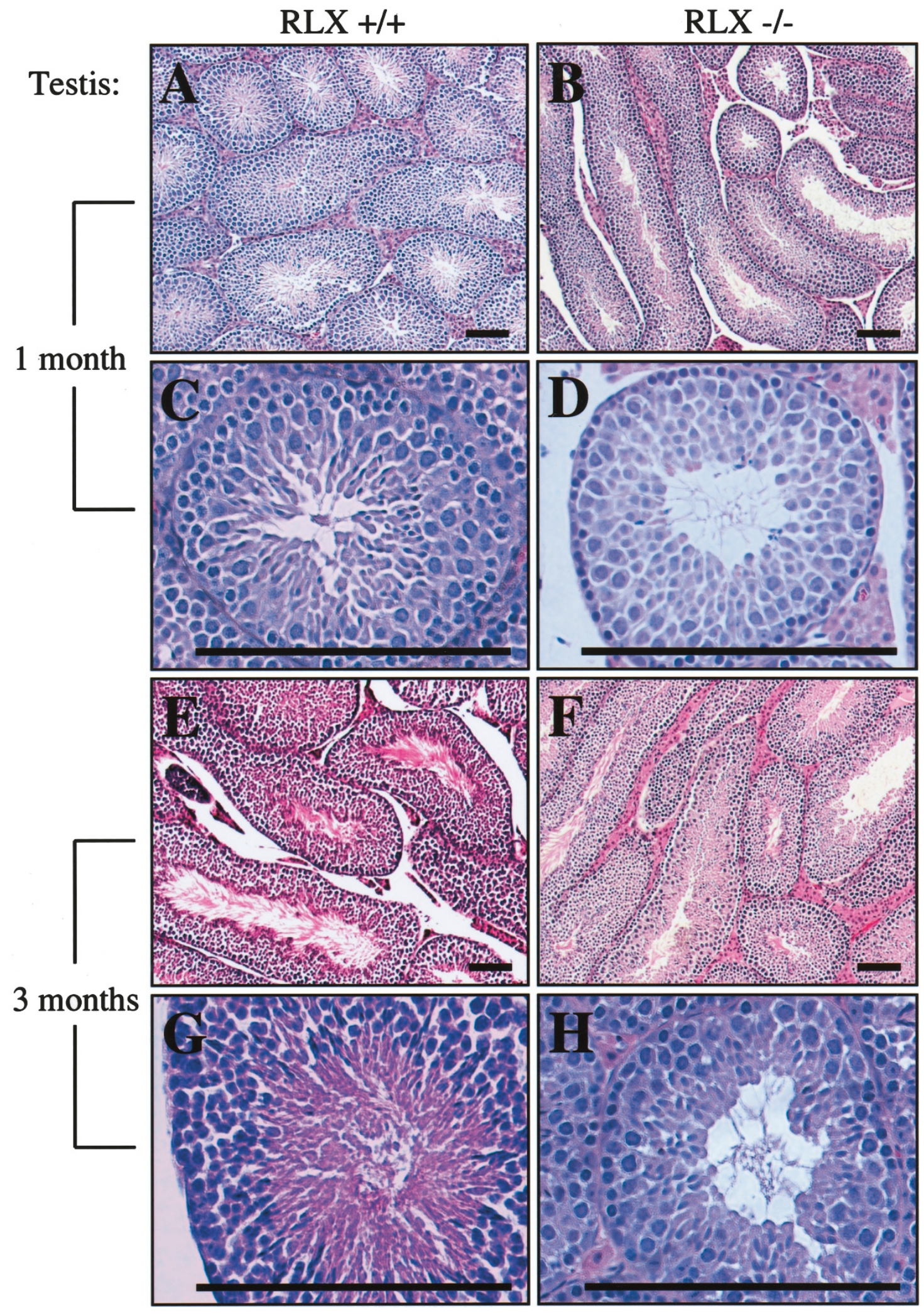

Figure 2.

Histology (hematoxylin and eosin staining) of seminiferous tubule and sperm maturation (testis) in RLX wild-type $(+/+)$ and RLX knockout $(-/-)$ mice, from 1 month to 3 months of age. Sections were derived from male $\mathrm{RLX}+/+$ and $\mathrm{RLX}-/-$ mouse reproductive tissues, respectively, at 1 month of age at low (A, B) and high magnification $(C, D)$ and at 3 months of age $(E$ to $H)$. Seminiferous testes tubules of RLX-/- mice were more compact but had decreased mature sperm (particularly at adulthood) compared with that found in tissues derived from $\mathrm{RLX}+/+$ mice, suggesting that a slower maturation of the male reproductive tract takes place in mice lacking relaxin. $B a r=0.1 \mathrm{~mm}$. 
the prostate of $\mathrm{RLX}+/+$ 1- and 3-month-old (Fig. 6M) mice showed weak positive staining for Bax. However, cells within the epithelial layer of the prostate of $\mathrm{RLX}-/$ mice had increased staining for Bax at 1 and 3 months of age (Fig. 6N).

Caspase- 9 staining was primarily associated with the germinal cells within the seminiferous tubules, rather than with spermatogonia or spermatocytes (data not shown). As with Bax, a significantly ( $p<$ $0.05)$ increased level of caspase- 9 staining was detected in 1-month-old RLX-/- mouse testes compared with that found in $\mathrm{RLX}+/+$ mouse sections (Table 2). With age $R L X-/-$ mouse tissues displayed higher levels of caspase- 9 positive cells compared with that found in $\mathrm{RLX}+/+$ mice (Table 2). No significant differences (between the groups) were observed in caspase- 9 expression in the epididymis and prostate at any age. These results support the hypothesis that relaxin may be linked to the regulation of sperm maturation and the epithelium secretory function of the prostate.

\section{Detection of Cell Proliferation}

The proliferating cell nuclear antigen (PCNA) antibody was used to detect cell proliferation based on its ability to associate with nuclear regions undergoing DNA synthesis. PCNA-positive cells were detected in immature and mature seminiferous tubules, with no significant difference in PCNA staining between $\mathrm{RLX}+/+$ and $\mathrm{RLX}-/-$ mice at 1 month and 3 months of age (data not shown). In immature tissues PCNA staining is usually highly expressed in mitotically active spermatogonia (which will die unless they replicate DNA), corresponding to proliferative activity. No staining for PCNA was detected in the epididymis derived from either $\mathrm{RLX}+/+$ or $\mathrm{RLX}-/-$ mice at 1 month and 3 months of age. These findings are consistent with the role of the epididymis in acting as a reservoir for mature sperm. Weak staining for PCNA was associated with the epithelial cells of prostate ducts derived from 1 month $\mathrm{RLX}+/+$ and $\mathrm{RLX}-/-$ mice. However, no staining for PCNA was detected from either group at 3 months of age (data not shown).

\section{Relaxin and Relaxin Receptor (LGR7) mRNA Expression in Male Mice}

To determine if relaxin and its receptor (LGR7) (Hsu et al, 2002) were produced locally within the male mouse, relaxin-1 and LGR7 mRNA expression were determined from the prostate and testis of both immature (6 week) and older adult (4-month, 6-month, and 12-month-old) RLX wild-type male mice. Relaxin-1 gene expression was identified in the mouse prostate at all ages studied and appeared to progressively increase with age (Fig. 7A). Relaxin-1 gene expression was also identified in the testis at all ages studied, with maximal levels observed at 4 months of age (Fig. 7A). LGR7 mRNA expression was also identified in the prostate and testis of ageing mice. Both tissues contained the full length region of LGR7
mRNA, which is required for functional activity of the receptor (Fig. 7B). LGR7 gene transcripts appeared to be highly expressed in the testis at all ages studied, compared with levels detected in the prostate. These findings confirm that murine relaxin and its receptor are expressed locally within the prostate and testis of the male mouse reproductive tract and suggest that both tissues are potential binding sites for relaxin.

\section{The Effects of Relaxin Gene Knockout on the Pregnancy Rate of Mice}

When $\mathrm{RLX}-/$ - male mice were first mated at 4 months of age, they were initially able to impregnate female $\mathrm{RLX}+/+$ mice at the same frequency as $\mathrm{RLX}+/+$ males (Fig. 8). However, as the age of the male $R L X-/-$ mice increased with time, the number of days between the delivery of each litter increased compared with that observed with the pairing of $\mathrm{RLX}+/+$ males with $\mathrm{RLX}+/+$ females. These data correlate with our observations on the underdevelopment of the male reproductive tract of $R L X-/-$ mice. However, they do not demonstrate with certainty as to whether the protracted littering of relaxin-null mice was due to a) less frequent copulation between mating pairs, or b) impaired fertility.

\section{Discussion}

The findings in this investigation clearly demonstrate an important role for relaxin in normal growth and development in male mice. Mice lacking a functional relaxin gene not only showed delayed growth (at a time when mice undergo puberty) but also had poorly developed male reproductive tracts from birth to adulthood. In addition to the physiologic phenotypes observed, histologic analyses of relaxin-null mutant male mice qualitatively demonstrated differences in the internal organization and maturation of the reproductive tract, some of which resembled that found in the vagina and nipple of female relaxin knockout mice (Zhao et al, 1999, 2000). These differences (some of which were clearly seen qualitatively and hence were not quantitated) included decreased sperm maturation (testis), increased collagen (testis, epididymis, and prostate), decreased epithelium/glandular tissue (prostate), and increased apoptotic cells (testis, epididymis, and prostate) compared with that found in $\mathrm{RLX}+/+$ animals. These data raise three important points of discussion: firstly, that relaxin's ability to stimulate a remodeling of the extracellular matrix of target tissues during normal growth and development is consistent with relaxin's previously described actions in other processes involving an unusual remodeling of the connective tissues (pregnancy and fibrotic diseases); secondly, they implicate the unexpected role of relaxin in the regulation of cell development; and thirdly, the lack of relaxin being associated with an increase in cell apoptosis.

Relaxin-deficient mice demonstrated the most noticeable lack of growth from birth to 1 month of age, which reflects a period when mammals undergo sig- 


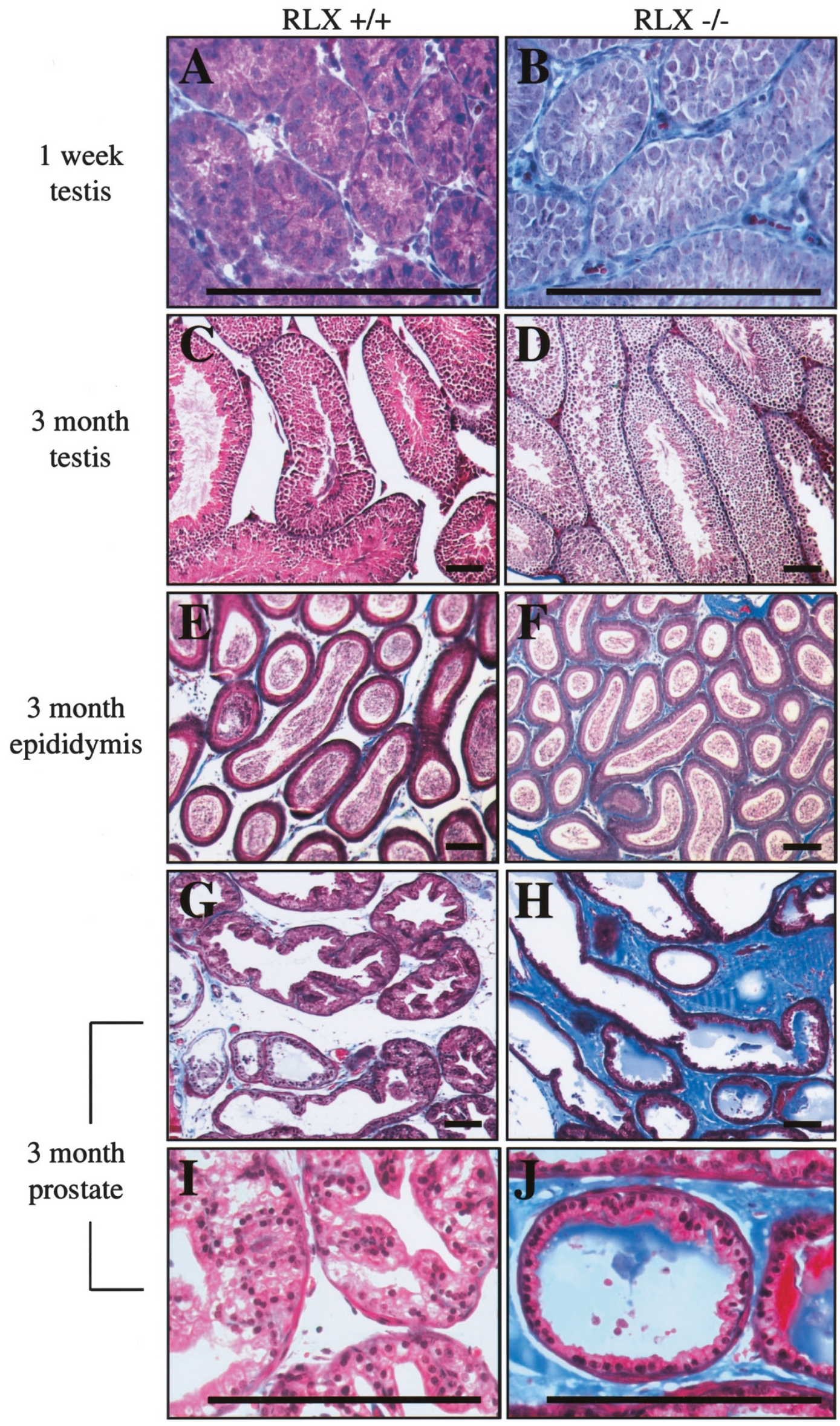


nificant changes in connective tissue turnover during development (Carvalho et al, 1993; Scott, 1990). These findings also correlate with the ability of relaxin to down-regulate collagen expression when stimulated by other cytokines (ie, TGF- $\beta$ and IL-1 $\beta$ ) or when induced by fibrotic disease (Unemori et al, 1990, 1993, 1996), but not under basal conditions. Although no direct evidence to date has linked relaxin to a role in mammalian development, indirect evidence suggests that relaxin may mediate its effects via the effects of estrogen (Arts et al, 1997; Ben-Hur et al, 1993; Pillai et al, 1999) and IGF-I (Huang et al, 1992; Ohleth et al, 1999); both of which are required for successful development and growth, especially during the mammalian growth spurt.

Unlike its effects on body growth, the finding that relaxin regulates the male reproductive tract confirms the findings of earlier investigations that demonstrated male reproductive tissues as being targets for relaxin activity (Brenner et al, 1984; Carrell et al, 1995; Essig et al, 1982; Ivell et al, 1989; Min and Sherwood, 1998; Weiss, 1989; Winslow et al, 1992; Yki-Jarvinen et al, 1983). Relaxin was previously identified in the seminal plasma of humans (Weiss, 1989; Winslow et al, 1992) in the peripheral circulation of boars (Juang et al, 1996) and was shown to enhance the penetration of human sperm into human or bovine cervical mucus (Brenner et al, 1984). In the current study, we demonstrated that the epithelium of the prostate gland derived from $R L X$ knockout mice were thinner and contained fewer high-secretory (columnar) cells but more lower-secretory (cuboidal) cells than those observed from $R L X$ wild-type animals, while the absence of relaxin correlated to elevated levels of cell apoptosis. Thus, this investigation implicates relaxin, not only in the developmental process of male reproductive tract organs, but also in the regulation of normal morphogenesis. Whether relaxin's effects on the extracellular matrix are a direct effect on matrix-producing cells or indirectly regulates cell development are yet to be determined. It is suggested that relaxin potentially binds to and regulates cell development (within specific target tissues) via its affinity to relaxin receptors or binding sites on the cells themselves.

The finding that the lack of relaxin was associated with increased staining of two markers (Bax and caspase-9) known to induce apoptosis in male reproductive tissues (testis, prostate, and epididymis) supports the hypothesis that relaxin may regulate celldeath processes. Both immature and adult (3 month) $\mathrm{RLX}-/-$ mice had tissues with increased staining of Bax (testis, epididymis, and prostate) and caspase- 9 (testis), as determined by immunohistochemical identification by two separate antibodies involved in separate but sometimes synergistic apoptotic cascades of events. The results of this investigation are consistent with previous reports, which did not investigate the physiologic function of relaxin but which demonstrated Bax expression in mouse and human male reproductive tissues (Krajewski et al, 1994; PenaultLlorca et al, 1998). They are also consistent with the finding that relaxin inhibited apoptosis in the cervix and vagina of pregnant rats (Zhao et al, 2001). Although only indirect evidence to date has suggested that caspase- 9 activity was involved in programmed cell death in mammalian reproduction (Inohara et al, 1998), our current findings confirmed that one means of relaxin-induced cell apoptosis in male reproduction is via regulation of the caspase protease family.

In addition to the above findings, we also demonstrated that relaxin and its receptor (LGR7) were expressed in the prostate and testis of the normal male mouse, suggesting that both tissues may be potential sources of relaxin in addition to being potential binding sites. This finding is consistent with previous evidence demonstrating localization and expression of relaxin from the prostate of other mammalian species (Gunnersen et al, 1995; Sokol et al, 1989). These findings further suggest a number of possibilities that could explain the reported differences between normal mice and relaxin gene knockout mice: a) that relaxin may act as an autocrine factor on the tissues it is expressed in, b) that relaxin expressed in the prostate may eventually act as a paracrine factor on other male reproductive tract tissues via the seminal fluid, and c) that relaxin expressed in the testis is required for the development of the other androgendependent tissues (prostate, epididymis, and seminal vesicle). The early occurrence of excess interstitial collagen in the testis of $\mathrm{RLX}-/-$ mice may have prevented adequate development of seminiferous tubule and Leydig cell development and function. This in turn may have resulted in lower androgen production, and hence, the poor development of androgendependent tissues, resulting in a reduction in spermatogenesis and perhaps reproductive performance.

In conclusion, this investigation demonstrates that relaxin plays an important role in mammalian growth and development, reflecting relaxin's role in connective tissue remodeling. Mice lacking a functionally active relaxin gene underwent delayed growth in addition to a slower rate of male reproductive tissue maturation and development, which was characterized by relaxin-null mutant mice undergoing reduced tissue organization, decreased sperm maturation, increased connective tissue (collagen), and increased cell apoptosis. These findings suggest that the progressively delayed maturation of the male reproductive tract found in $\mathrm{RLX}-/-$ mice may correlate to the problems male relaxin knockout mice had in insemi-

\footnotetext{
Figure 3.

Masson trichrome staining of collagen within the testis of 1-week (A, B) and 3-month-old (C, D) mice, the epididymis of 3-month-old animals (E, F), and the prostate of 3-month-old RLX $+/+$ and $R L X-/-$ mice $(G$ to $\mathrm{J})$. At all ages investigated, testis and epididymis tubules and prostate ducts of RLX-/- mice were surrounded by increased collagen compared with $\mathrm{RLX}+/+$ mouse tissues. Prostate tissues from adult $\mathrm{RLX}+/+$ mice also contained normal glandular epithelium, associated with an increase in cell number $(G, I)$; whereas prostate glands of $R L X-/-$ mice contained a smaller epithelial lining, associated with fewer cells $(H, J)$. Bar $=0.1 \mathrm{~mm}$ (A to $\mathrm{H})$. Bar $=0.05 \mathrm{~mm}(\mathrm{I}, \mathrm{J})$
} 


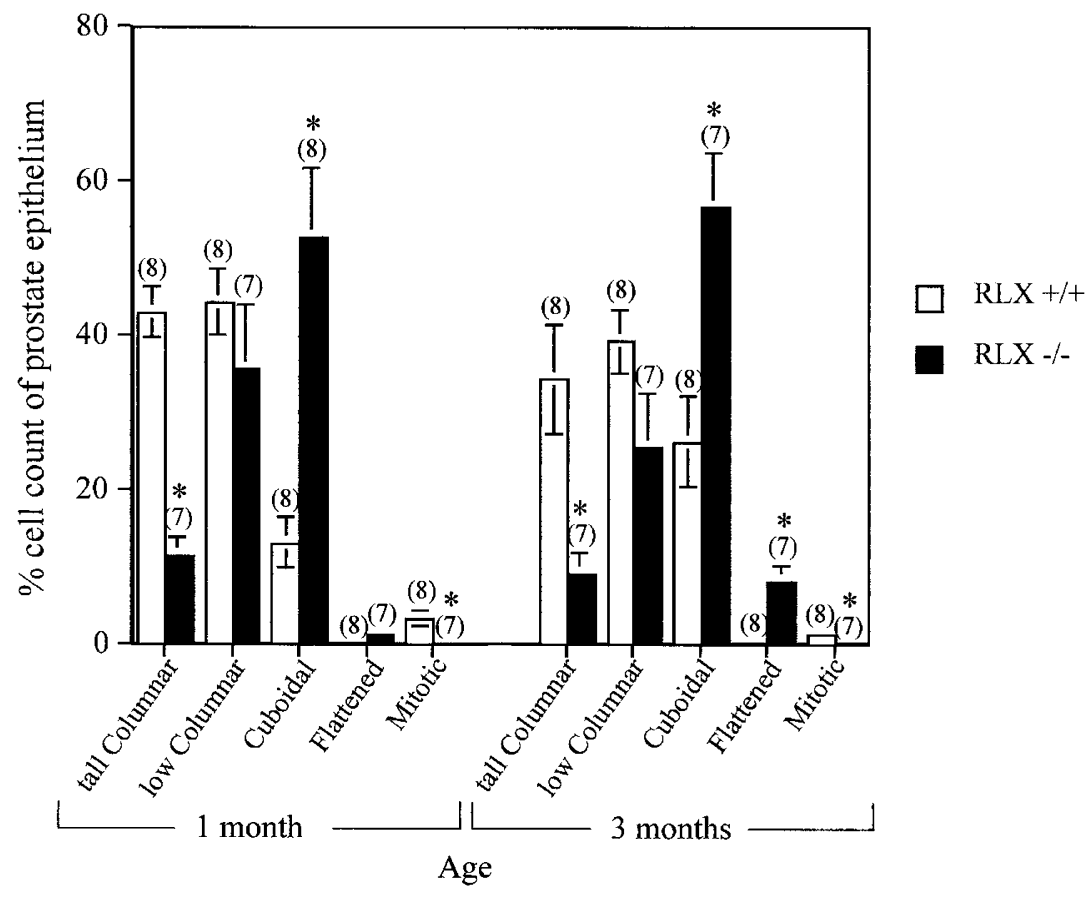

Figure 4.

Quantitative analysis of prostate cell epithelium. At least 100 cells in four separate areas of the prostatic tissue sections (stained with hematoxylin and eosin) from several $\mathrm{RLX}+/+$ and $\mathrm{RLX}-/-$ mice were sequentially counted. The percentage of cells exhibiting low and tall columnar, cuboidal, flattened, and mitotic characteristics was then determined. Numbers in parenthesis represent the number of mice used in each group. An asterisk denotes a difference of $p<0.05$.

nating normal female mice, particularly as they aged. Based on these observations, we postulate that relaxin not only plays a previously unexpected role in normal mammalian growth but may also enhance male fertility.

\section{Materials and Methods}

\section{Animals}

$\mathrm{RLX}+/+$ (wild-type), RLX+/- (heterozygous), and RLX-/- (homozygous) mice (Zhao et al, 1999) were generated from RLX+/- (129SV/C57Blk6J) parents for these studies. All animals were housed in a controlled environment and maintained on a 14-hour light, 10-hour dark schedule, with access to Labdiet rodent lab chow (Deans Animal Feed, San Bruno, California) and water. These experiments were approved by the Institute's Animal Experimental Ethics Committee, which adheres to the National Institutes of Health Code of Practice for the care and use of laboratory animals.

\section{Genotyping by PCR}

Mouse DNA was isolated by lysing tail tissue (5 to 7 $\mathrm{mm}$ ) in $400 \mu \mathrm{l}$ of PCR lysis buffer, containing $50 \mathrm{~mm}$ Tris- $\mathrm{HCl}, \mathrm{pH} 8,0.5 \%$ SDS, $0.1 \mathrm{M}$ EDTA, and $1 \mathrm{mg} / \mathrm{ml}$ proteinase K (Gibco BRL, Gaithersburg, Maryland) at 50 to $55^{\circ} \mathrm{C}$ overnight. Digested samples were then mixed with $3 \mathrm{M}$ sodium acetate $(40 \mu \mathrm{l})$, buffer saturated phenol $(200 \mu \mathrm{l})$ and chloroform $(200 \mu \mathrm{l})$ in serum Vacutainer tubes before samples were centrifuged at $3000 \mathrm{rpm}$ for 10 minutes. The DNA (contained in the upper aqueous phase) was decanted into separate microcentrifuge tubes containing isopropyl alcohol $(240 \mu l)$ to precipitate the DNA before samples were vortexed and spun and the supernatant discarded. The remaining DNA pellet was dissolved in 40 to $50 \mu \mathrm{l}$ of sterile water. For PCR, each DNA template $(1 \mu \mathrm{l})$ was used in a $30-\mu$ l reaction mixture containing $2.5 \mathrm{U}$ Taq polymerase (PGC Scientific, Gaithersburg, Maryland) and $150 \mathrm{ng}$ of each of the RLX+/+ and RLX $-/-$ primers, designed by Zhao and colleagues (Zhao et al, 1999). The amplification protocol used and detection of PCR products were performed as described before (Zhao et al, 1999).

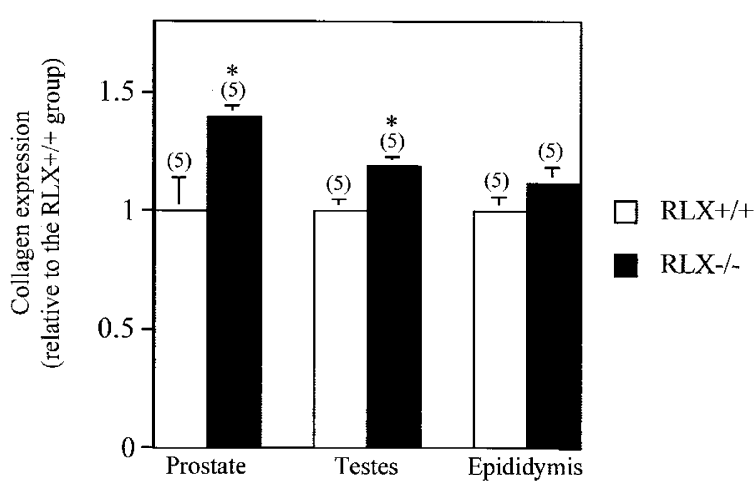

Figure 5.

Collagen expression in the prostate, testes, and epididymis of 6-month-old $\mathrm{RLX}+/+$ and $\mathrm{RLX}-/-$ mice as determined by hydroxyproline analysis. An asterisk denotes a difference of $p<0.05$. Collagen expression in RLX-/mouse tissues was expressed as a ratio of collagen in $R L X+/+$ mouse tissues, which was always expressed as 1 . 


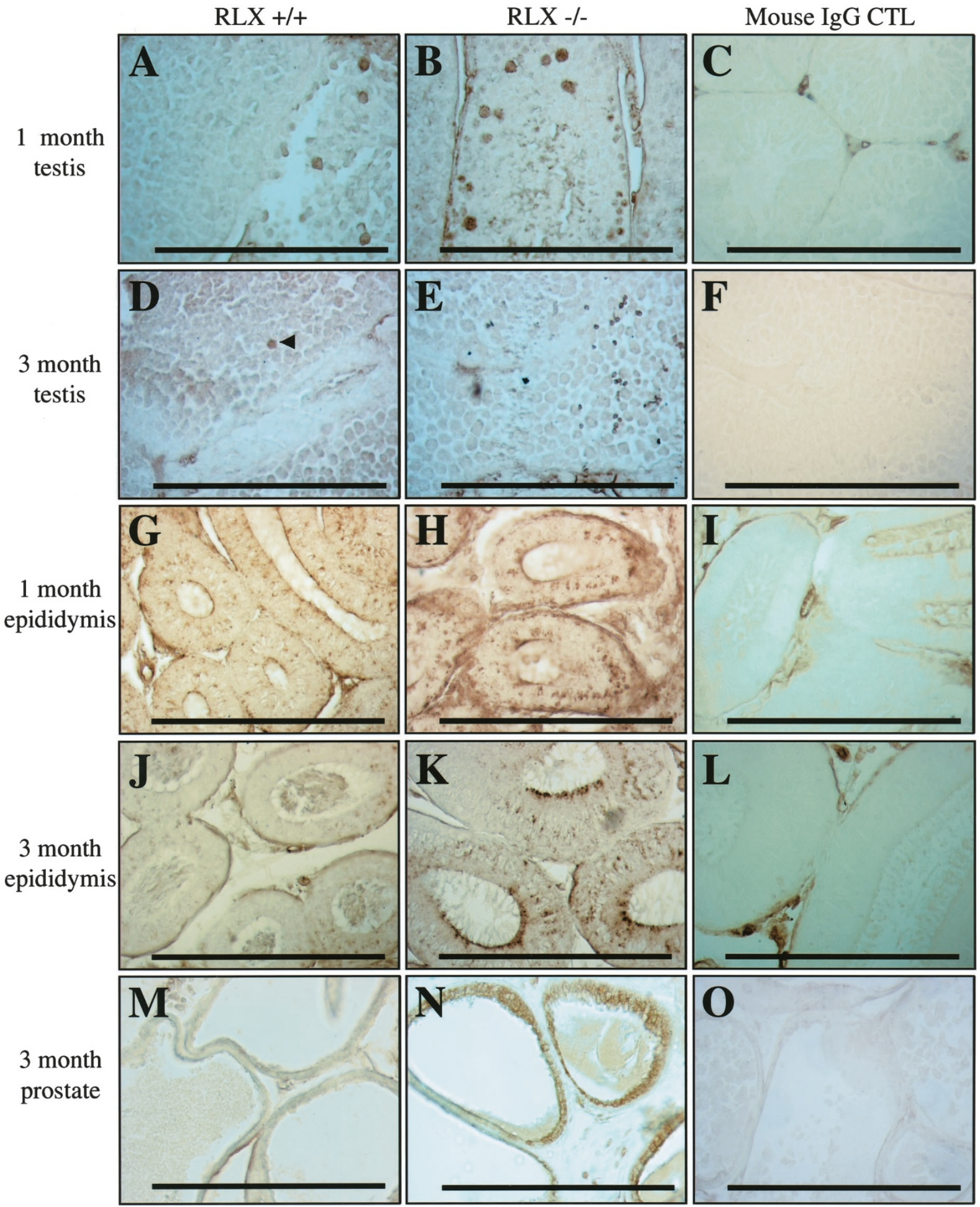

Figure 6.

Antibody staining of Bax protein in male mouse reproductive tissues. Bax staining (brown cells) was detected in 1-month (A, B) and 3-month-old (D, E) testis tubules (germ cells); 1-month ( $\mathrm{G}, \mathrm{H}$ ) and 3-month-old (J, K) epididymis tubules (epithelial cells); and 3-month-old prostate glands (epithelial cells) (M, N) of RLX+/+ and $\mathrm{RLX}-/$ - mice, respectively. A significantly increased level of Bax staining was observed in all tissues of $R L X-/-$ mice. A mouse Ig G negative control (C, F, I, L, 0 ) was also used in all experiments performed. Bar $=0.1 \mathrm{~mm}$.

\section{Tissue Collection and Histology}

Relaxin $+/+$, RLX+/-, and RLX-/- male and female mice $(n \geq 20$ in each of the six groups) were obtained at 1 week, 1 month, 2 months, and 3 months of age and weighed. All animals were litter mates, produced from $R L X+/-$ parents and hence, did not require foster mothering. The animals were examined in the same facility and at the same time points (mentioned 
Table 2. Detection of Bax and Caspase-9 Positive Cells in the Testis of 1- and 3-month-old RLX+/+ and RLX-/- Mice

\begin{tabular}{ccc}
\hline & $\begin{array}{c}\text { RLX }+/+ \\
\text { Cell/mm² } \\
\text { [Mean } \pm \text { SE (n)] }\end{array}$ & $\begin{array}{c}\text { RLX-/- } \\
\text { Cell/mm² } \\
{[\text { Mean } \pm \text { SE (n)] }}\end{array}$ \\
\hline Bax staining & & \\
1 month of age & $0.8 \pm 0.2(6)$ & $2.5 \pm 0.4(6)^{a}$ \\
3 months of age & $0.1(6)$ & $2.6 \pm 0.5(6)^{a}$ \\
Caspase-9 staining & & \\
1 month of age & $1.7 \pm 0.3(7)$ & $5.9 \pm 0.8(6)^{a}$ \\
3 months of age & $1.0 \pm 0.1(6)$ & $3.6 \pm 0.6(5)^{a}$ \\
\hline
\end{tabular}

${ }^{a} p<0.05$ (when compared with age-matched $\mathrm{RLX}+/+$ stained cell numbers $/ \mathrm{mm}^{2}$ ).

above) from birth. $\mathrm{RLX}+/+$ and $\mathrm{RLX}-/-$ male mice were then killed under anesthesia with carbon dioxide for tissue collection. The male reproductive tracts (including testis, epididymis, prostate, and seminal vesicle) were collected from each animal at 1 week ( $n$ $=10 \mathrm{RLX}+/+$ male mice; $n=11-/-$ male mice), 1 month $(n=10 \mathrm{RLX}+/+$ male mice, $n=10-/-$ male mice), and 3 months of age ( $n=10 \mathrm{RLX}+/+$ male mice, $n=10 \mathrm{RLX}-/-$ male mice). Individual tissue were weighed and then fixed in $10 \%$ formalin for histologic analysis.

Tissues were processed, paraffin embedded, and cut (4- $\mu \mathrm{m}$ sections) using an AO Spencer 820 microtome and placed on poly-L-lysine-coated glass slides. Consecutive sections from each tissue were stained with hematoxylin and eosin and for collagen, with Masson trichrome staining kit (Richard-Allan Scientific, Kalamazoo, Michigan) as described by the manufacturer. The stained slides were viewed using a Zeiss Axioplan-2 microscope and the images captured by digital camera (Hamamatsu) and stored for

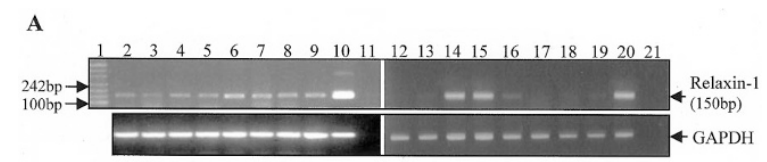

B

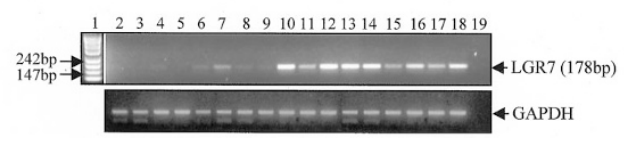

Figure 7.

PCR analysis of relaxin-1 (A) and LGR7 (B) mRNA expression from the mouse prostate and testis. Reverse transcription PCR was performed on CDNA samples from two separate tissues from each age group. (A) Samples consist of a size marker (Lane 1); duplicate prostate tissue extracts from 6-week-old, 4-month old, 6-month-old, and 12-month-old RLX+/+ mice (Lanes 2 to 9); and duplicate testis tissue extracts from the same ages (Lanes 12 to 19). Also included are the positive controls from a pregnant female $(R L X+/+)$ ovarian tissue extract (Lanes 10 and 20) and no DNA controls (Lanes 11 and 21). (B) Samples consist of a size marker (Lane 1); duplicate prostate tissue extracts from 6-week-old, 4-month old, 6-month-old, and 12-month-old RLX+/+ mice (Lanes 2 to 9); and duplicate testis tissue extracts from the same ages (Lanes 10 to 17). Brain cDNA from a male mouse was used as a positive control (Lane 18); a no DNA control is also shown (Lane 19). A housekeeping gene, GAPDH, was also added to ensure equal loading of the cDNAs in all PCRs. retrieval and analysis. The images were digitally enhanced for maximum contrast and brightness using Adobe Photoshop (Adobe Systems, Inc., Mountain View, California).

\section{Antibody Staining for Cell Apoptosis and Proliferation}

The tissues from the reproductive tract of 1 - and 3-month-old male mice were mounted on precoated slides, deparaffinized, and hydrated. The samples were then stained using an Immunocruz staining system using a horseradish peroxidase-streptavidin complex (Santa Cruz Biotechnology, Inc., Santa Cruz, California) in a humidified atmosphere. Tissue sections were initially treated with a peroxidase blocker (to quench endogenous peroxidase activity) for 5 minutes before being preblocked in goat serum (20 minutes). Serial sections from each RLX+/+ and RLX-/- tissue sample were then incubated with either a Bax monoclonal $\mathrm{lg} \mathrm{G}$ primary antibody $(4 \mu \mathrm{g} / \mathrm{ml})($ Santa Cruz Biotechnology, Inc.), a caspase-9 polyclonal Ig G antibody (4.5 $\mu \mathrm{g} / \mathrm{ml})$ (Santa Cruz Biotechnology, Inc.), or a PCNA (Santa Cruz Biotechnology, Inc.) monoclonal $\mathrm{lg} \mathrm{G}$ antibody $(4 \mu \mathrm{g} / \mathrm{ml})$ for 2 hours at $37^{\circ} \mathrm{C}$. Depending on the type of antibody used, either a mouse Ig $G$ or rabbit Ig $G$ antibody (Santa Cruz Biotechnology, Inc.) was used as a negative control (2 hours) in all experiments performed. Samples were washed in PBS for 2 minutes and subjected to the appropriate secondary antibody (goat anti-mouse lg G or goat antirabbit $\lg G$ ) for 30 minutes then were washed as above for 2 minutes. The samples were then treated with a horseradish peroxidase-streptavidin complex (30 to 45 minutes) and incubated with a diaminobenzidine chromagen substrate (2 to $10 \mathrm{~min}$ utes), which was prepared in accordance with the manufacturer's instructions. The slides were then washed in distilled water (2 minutes) before being dehydrated from $95 \%$ alcohol to xylene and mounted and then photographed as described above.

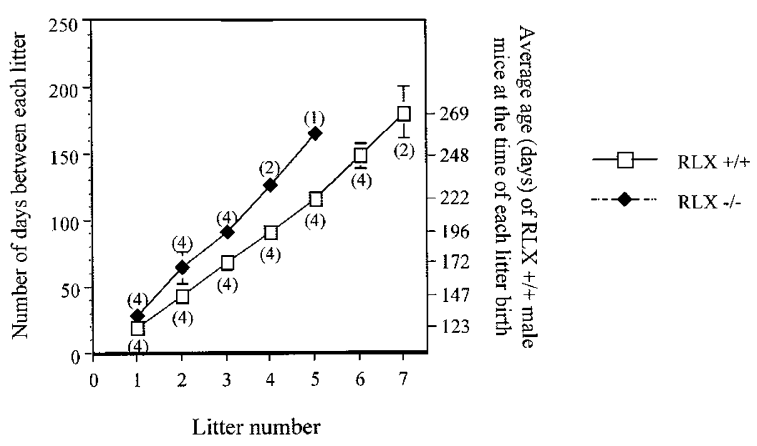

Figure 8 .

The mean $( \pm \mathrm{SE})$ number of days taken by $R L X+/+$ male and female pairs (solid line) and $\mathrm{RLX}-/-$ male/RLX $+/+$ female pairs (dotted line) to produce pups over a 5-month period. The number of litters produced by each set of pairs was also plotted against the average age of $R L X+/+$ and $R L X-/-$ male mice at the time of each litter. As the age of the male $R L X-/-$ mice increased (over 4 months of age), the number of days taken by their female $R L X+/+$ breeding partners to give birth to pups increased with each litter compared with that produced by $\mathrm{RLX}+/+$ pairs. 


\section{Analysis of Histological Sections}

Serial sections from 5 to 10 separate $R L X+/+$ and $\mathrm{RLX}-/-$ mouse tissues, respectively, were used for the various staining procedures employed and the following parameters measured as follows.

Sperm Maturation. Immature sperm indicates germ cells undergoing spermiation at all stages (from spermatogonia to spermatids), whereas mature sperm were identified histologically as those attached to a sperm tail. All stages of spermatogenesis were studied in testis tubules (by observing all tubules contained within each tissue section).

Examination of Prostate Gland Epithelial Cell Morphology. Sections of the prostatic tissue, stained with hematoxylin and eosin, were examined for glandular epithelial cell morphology. We determined the percentage of cells exhibiting cuboidal, low and tall columnar, flattened, and mitotic characteristics in $\mathrm{RLX}+/+(n=6$ to 8$)$ and RLX $-/-(n=6$ to 8$)$ mice. Cells (at least 100) in four separate areas of the prostatic tissue from each specimen were sequentially counted.

Quantitation of Apoptotic Cells. Sections from the testis, epididymis, and prostatic tissues from 5 to 7 separate $R L X+/+$ and $R L X-/-$ mice were screened for positively stained apoptotic cells, which were counted and expressed per area $\left(\mathrm{mm}^{2}\right)$ of each tissue section analyzed. Several sections from each mouse tissue were screened with each stain and a representative slide chosen for figure presentation.

\section{Measurement of Collagen Content in the Prostate, Testis, and Epididymis}

To confirm the histologic observations on collagen in male reproductive tract tissues, the prostate, combined testes, and combined epididymis from separate 6-month-old RLX $+/+(n=5)$ and RLX-/- $(n=5)$ male mice were collected and analyzed for hydroxyproline/collagen content as described before (Samuel et al, 1996). Hydroxyproline analysis of tissues were conducted on slightly older animals to confirm the hypothesis that relaxin-deficient mice undergo a progressive increase in collagen with age, resulting in increased collagen deposition as observed in other tissues (Amento et al, 2001; Samuel et al, 2003) by approximately 6 months of age.

\section{RNA Extraction of Tissue and Reverse Transcription (RT)-PCR}

To identify the potential source of relaxin-1 and its receptor (LGR7) in the male mouse, the prostate and testis from 6-week ( $n=2$ per tissue), 4-month ( $n=2$ per tissue), 6-month ( $n=2$ per tissue), and 12-monthold ( $n=2$ per tissue) RLX $+/+$ male mice were collected, weighed, and milled in the presence of liquid nitrogen within 5 minutes of death. The ovaries of a pregnant female RLX wild-type mouse were used as a positive control for relaxin-1, while mouse brain was used as a positive control for LGR7 expression. The milled samples were immediately subjected to and homogenized with TriZOL reagent (Gibco-BRL, Rockville, Maryland) and the RNA extracted (according to the manufacturer's instructions) before being quantitated by absorbance at $260 \mathrm{~nm}$. One to $2 \mu \mathrm{g}$ of total RNA from each sample was used for the RT reaction, which was performed using the Thermoscript RT-PCR kit (Gibco-BRL) in a 20- $\mu$ l volume (according the manufacturer's instructions). Primer sequences and PCR conditions for relaxin-1 are detailed elsewhere (Bathgate et al, 2002). The following forward (5' TTTAGGAAGTAATAAGATTGA 3') and reverse (5' TTGTTGGATATTTGAAATTTC $3^{\prime}$ ) primers were used to detect mouse LGR7 (178 bp). For LGR7, touch-down PCR using the following annealing temperatures was used: $58^{\circ} \mathrm{C}$ ( 2 cycles), $56^{\circ} \mathrm{C}$ ( 2 cycles), $54^{\circ} \mathrm{C}\left(2\right.$ cycles), $52^{\circ} \mathrm{C}$ ( 2 cycles), $50^{\circ} \mathrm{C}$ ( 2 cycles), and $48^{\circ} \mathrm{C}$ (30 cycles). The housekeeping gene, GAPDH, was also added to ensure equal loading of the CDNA. The PCR reactions were completed in a Perkin Elmer Gene Amplifier using the amplification protocols described above and previously (Bathgate et al, 2002), before equal aliquots of the PCR products were subjected to electrophoresis on $2 \%(\mathrm{w} / \mathrm{v})$ agarose gels (stained with ethidium bromide) and photographed.

\section{Determination of Pregnancy Rate between RLX+/+ and RLX-/- Mice}

To determine if the insemination rate of $R L X$ knockout mice differed to that of RLX wild-type mice, four $\mathrm{RLX}-/$ - male mice and four $\mathrm{R} L \mathrm{X}+/+$ male mice were paired with $R L X+/+$ female mice in separate cages. Male and female mice used in these studies were 4 months of age, and all pairings remained in the same cage for the duration of the study. The date that each litter was born from each of the eight pairings was recorded over a 5-month period, and the litter number was plotted against the number of days between the birth of each litter. The average age of RLX-/- or $\mathrm{RLX}+/+$ male mice at the time of each litter birth was also recorded.

\section{Statistical Analysis}

The results were analyzed using a one-way ANOVA test. All data in this paper are presented as the mean \pm SEM, with $p<0.05$ described as statistically significant.

\section{Acknowledgements}

We sincerely thank Mr. Blake Nichols and Mr. Jeremy Young for their assistance with animal maintenance, Mr. Gil Asio for his assistance with the histology and Ms. Chongxin Zhao for her assistance with molecular biology. We also thank Mr. Daniel Scott for the mouse LGR7 RT-PCR primers, Dr. Gary Greenberg for the use of a Zeiss Axioplan-2 microscope, and Professor Felix Beck for helpful discussion and review of the manuscript. 


\section{References}

Amento EP, Samuel CS, Hu M, and Tian H (2001). Deletion of the relaxin gene causes age-related progressive dermal fibrosis (Abstract). Arthritis Rheum 44:847.

Arts J, Kuiper GG, Janssen JM, Gustafsson JA, Lowik CW, Pols HA, and van Leeuwen JP (1997). Differential expression of estrogen receptors $\alpha$ and $\beta$ mRNA during differentiation of human osteoblasts SV-HFO cells. Endocrinology 138:50675070 .

Bathgate RAD, Samuel CS, Burazin TCD, Layfield S, Claasz AA, Reytomas IGT, Dawson NF, Zhao C, Bond C, Summers RJ, Parry LJ, Wade JW, and Tregear GW (2002). Human relaxin gene $3(\mathrm{H} 3)$ and the equivalent mouse relaxin (M3) gene: Novel members of the relaxin peptide family. $J$ Biol Chem 277:1148-1157.

Ben-Hur H, Mor G, Blickstein I, Likhman I, Kohen F, Dgani R, Insler V, Yaffe P, and Ornoy A (1993). Localization of estrogen receptors in long bones and vertebrae of human fetuses. Calcif Tiss Int 53:91-96.

Brenner JH, Lessing JB, Schoenfeld C, Amelar RD, Dubin L, and Weiss $G$ (1984). Stimulation of human sperm cervical mucus penetration in vitro by relaxin. Fertil Steril 42:92-96.

Carrell DT, Peterson CM, and Urry RL (1995). The binding of recombinant human relaxin to human spermatozoa. Endocrin Res 21:697-707.

Carvalho RS, Yen EH, and Suga DM (1993). The effect of growth on collagen and glycosaminoglycans in the articular disc of the rat temporomandibular joint. Arch Oral Biol 38:457-466.

Essig M, Schoenfeld C, D'Eletto RT, Amelar R, Steinetz BG, O'Byrne EM, and Weiss G (1982). Relaxin in human seminal plasma. Ann NY Acad Sci 380:224-230.

Goldsmith LT, Weiss G, and Steinetz BG (1995). Relaxin and its role in pregnancy. Endocrinol Metab Clin North Am 24:171-186.

Gunnersen JM, Crawford RJ, and Tregear GW (1995). Expression of the relaxin gene in rat tissues. Mol Cell Endocrinol 110:55-64.

Hsu SY, Nakabayashi K, Nishi S, Kumagai J, Kudo M, Sherwood OD, and Hsueh AJ (2002). Activation of orphan receptors by the hormone relaxin. Science 295:671-674.

Huang CJ, Li Y, Stromer H, and Anderson LL (1992). Synergistic effects of insulin-like growth factor I and gonadotrophins on relaxin and progesterone secretion by ageing corpora lutea of pigs. J Reprod Fertil 96:415-425.

Hwang JJ, Lee AB, Fields PA, Haab LM, Mojonnier LE, and Sherwood OD (1991). Monoclonal antibodies specific for rat relaxin. V. Passive immunization with monoclonal antibodies throughout the second half of pregnancy disrupts development of the mammary apparatus and, hence, lactational performance in rats. Endocrinology 129:3034-3042.

Inohara N, Gourley TS, Carrio R, Muniz M, Merino J, Garcia I, Kokeshi T, Hu Y, Chen S, and Nunez G (1998). Diva, a Bcl-2 homologue that binds directly to Apaf-1 and induces BH3independent cell death. J Biol Chem 273:32479-32486.

Ivell R, Hunt N, Khan-Dawood F, and Dawood MY (1989). Expression of the human relaxin gene in the corpus luteum of the menstrual cycle and in the prostate. Mol Cell Endocrinol 66:251-255.
Juang HH, Musah Al, Scwabe C, and Anderson LL (1996). Relaxin in peripheral plasma of boars during development, copulation, after administration of hCG and after castration. $J$ Reprod Fertil 107:1-6.

Krajewski S, Krajewska M, Shabaik A, Miyashita T, Wang HG, and Reed JC (1994). Immunohistochemical determination of in vivo distribution of Bax, a dominant inhibitor of $\mathrm{Bcl}-2$. Am J Pathol 145:1323-1336.

Kuenzi MJ and Sherwood OD (1992). Monoclonal antibodies specific for rat relaxin. VII. Passive immunization with monoclonal antibodies throughout the second half of pregnancy prevents development of normal mammary nipple morphology and function in rats. Endocrinology 131:1841-1847.

Kuida K (2000). Caspase-9. Int J Biochem Cell Biol 32:121124.

Min G and Sherwood OD (1998). Localization of specific relaxin-binding cells in the ovary and testis of pigs. Biol Reprod 59:401-408.

Ohleth KM, Zhang Q, Lenhart JA, Ryan PL, and Bagnell CA (1999). Trophic effects of relaxin on reproductive tissue: Role of the IGF-I system. Steroids 64:634-639.

Oltvai ZN, Milliman CL, and Korsmeyer SJ (1993). Bcl-2 heterodimerizes in vivo with a conserved homolog, Bax, that accelerates programmed cell death. Cell 74:609-619.

Osheroff PL, Cronin MJ, and Lofgren JA (1992). Relaxin binding in the rat heart atrium. Proc Natl Acad Sci USA 89:2384-2388.

Osheroff PL and Ho WH (1993). Expression of relaxin mRNA and relaxin receptors in postnatal and adult rat brains and hearts. Localization and developmental patterns. J Biol Chem 268:15193-15199.

Osheroff PL and Phillips HS (1991). Autoradiographic localization of relaxin binding sites in rat brain. Proc Natl Acad Sci USA 88:6413-6417.

Parry LJ, Hornsby DJ, Poterski RS, Wilson BC, Summerlee AJS (2001). Testicular descent in rats: a role for relaxin? In: Tregear GW, Ivell R, Bathgate RAD, and Wade JD, editors. Proceedings of the Third International Conference on Relaxin and Related Peptides. The Netherlands: Kluwer Acedmic Publishers, 347-348.

Parsell DA, Mak JY, Amento EP, and Unemori EN (1996). Relaxin binds to and elicits a response from cells of the human monocytic cell line, THP-1. J Biol Chem 271:2793627941.

Penault-Llorca F, Bouabdallah R, Devilard E, Charton-Bain MC, Hassoun J, Birg F, and Xerri L (1998). Analysis of Bax expression in human tissues using the anti-Bax, 411 monoclonal antibody on paraffin sections. Pathol Res Pract 194: 457-464.

Pillai S, Rockwell C, and Sherwood OD (1999). Relaxin stimulates uterine edema via activation of estrogen receptor: Blockade of its effects using ICI 182, 780, a specific estrogen receptor antagonist. Endocrinology 140:2426-2429.

Samuel CS, Butkus A, Coghlan JP, and Bateman JF (1996). The effects of relaxin on collagen metabolism in the nonpregnant rat pubic symphysis: The influence of estrogen and progesterone in regulating relaxin activity. Endocrinology 137:3884-3890.

Samuel CS, Zhao C, Bathgate RAD, Bond CP, Burton MD, Parry LP, Summers RJ, Tang MLK, Amento EP, and Tregear 
GW (2003). Relaxin deficiency in mice is associated with an age-related progression of pulmonary fibrosis. FASEB $\mathrm{J}$ 17:121-123.

Schwabe C and McDonald JK (1977). Relaxin: A disulfide bond homolog of insulin. Science 197:914-915.

Scott JE (1990). Proteoglycan: Collagen interactions and subfibrillar structure in collagen fibrils. Implications in the development and ageing of connective tissues. J Anat 169: 23-35.

Sherwood OD (1994). Relaxin. In: Knobil E, Niell J, editors. Physiology of Reproduction. New York: Raven Press, 8611009.

Sokol RZ, Wang XS, Lechago J, Johnston PD, and Swerdloff RS (1989). Immunohistochemical localization of relaxin in human prostate. J Histochem Cytochem 37:1253-1255.

Steinetz BG, Schwabe C, Callard IP, and Goldsmith LT (1998). Dogfish shark (Squalus acanthias) testes contain a relaxin. J Androl 19:110-115.

Tan YY, Wade JD, Tregear GW, and Summers RJ (1999). Quantitative autoradiographic studies of relaxin binding in rat atria, uterus and cerebral cortex: Characterization and effects of oestrogen treatment. Br J Pharmacol 127:91-98.

Unemori EN and Amento EP (1990). Relaxin modulates synthesis and secretion of procollagenase and collagen by human dermal fibroblasts. J Biol Chem 265:10681-10685.

Unemori EN, Beck LS, Lee WP, Xu Y, Siegel M, Keller G, Liggitt HD, Bauer EA, and Amento EP (1993). Human relaxin decreases collagen accumulation in vivo in two rodent models of fibrosis. J Invest Dermatol 101:280-285.

Unemori EN, Pickford LB, Salles AL, Piercy CE, Grove BH, Erikson ME, and Amento EP (1996). Relaxin induces an extracellular matrix-degrading phenotype in human lung fibroblasts in vitro and inhibits lung fibrosis in a murine model in vivo. J Clin Invest 98:2739-2745.
Weiss G (1989). Relaxin in the male. Biol Reprod 40:197-200.

Weiss G, Goldsmith LT, Schoenfeld C, and D'Eletto R (1986). Partial purification of relaxin from human seminal plasma. Am J Obstet Gynecol 154:749-755.

Winslow JW, Shih A, Bourell JH, Weiss G, Reed B, Stults JT, and Goldsmith LT (1992). Human seminal relaxin is a product of the same gene as human luteal relaxin. Endocrinology 130:2660-2608.

Wyatt TA, Sisson JH, Forget MA, Bennett RG, Hamel FG, and Spurzem JR (2002). Relaxin stimulates bronchial epithelial cell PKA activation, migration, and ciliary beating. Exp Biol Med 227:1047-1053.

Yki-Jarvinen H, Wahlstrom T, and Seppala M (1983). Immunohistochemical demonstration of relaxin in the genital tract of men. J Reprod Fertil 69:693-695.

Zhao L, Roche PJ, Gunnersen JM, Hammond VE, Tregear GW, Wintour EM, and Beck F (1999). Mice without a functional relaxin gene are unable to deliver milk to their pups. Endocrinology 140:445-453.

Zhao L, Samuel CS, Tregear GW, Beck F, and Wintour EM (2000). Collagen studies in late pregnant relaxin null mice. Biol Reprod 63:697-703.

Zhao S, Fields PA, and Sherwood OD (2001). Evidence that relaxin inhibits apoptosis in the cervix and the vagina during the second half of pregnancy in the rat. Endocrinology 142:2221-2229. 